\title{
Adherence to antidepressant medications: an evaluation of community pharmacists' counseling practices [Corrigendum]
}

\author{
Chong WW, Aslani P, Chen TF. Patient Prefer Adherence. \\ 2013;7:813-825.
}

On page 815, Figure 1 should have the following note listed beneath it: "Note: Reprinted from Res Social Adm Pharm, Chong WW, Aslani P, Chen TF, Pharmacist-patient communication on use of antidepressants: A simulated patient study in community pharmacy, Epub, Copyright (C) 2013, with permission from Elsevier. ${ }^{27}$,

\section{Publish your work in this journal}

Patient Preference and Adherence is an international, peer-reviewed, open access journal focusing on the growing importance of patient preference and adherence throughout the therapeutic continuum. Patient satisfaction, acceptability, quality of life, compliance, persistence and their role in developing new therapeutic modalities and compounds to optimize clinical outcomes for existing disease states are major areas of interest. This journal has been accepted for indexing on PubMed Central. The manuscript management system is completely online and includes a very quick and fair peer-review system. Visit http://www.dovepress.com/ testimonials.php to read real quotes from published authors. 